\title{
The Recruitment Pattern of Liza falcipinnis from Elechi Creek, Upper Bonny, Niger Delta, Nigeria
}

\author{
Awoteinm Dateme Isaiah George ${ }^{1}$, Jasper Freeborn Nestor Abowei ${ }^{2}$ \\ ${ }^{1}$ Department of Fisheries and Aquatic Environment, Faculty of Agriculture, Rivers State University, \\ Port Harcourt, Nigeria \\ ${ }^{2}$ Department of Biological Sciences, Faculty of Science, Niger Delta University, Wilberforce Island, Nigeria \\ Email: pstawogeorge@yahoo.com, cebealse@yahoo.com
}

How to cite this paper: George, A.D.I. and Abowei, J.F.N. (2018) The Recruitment Pattern of Liza falcipinnis from Elechi Creek, Upper Bonny, Niger Delta, Nigeria. Open Access Library Journal, 5: e4457. https://doi.org/10.4236/oalib.1104457

Received: February 28, 2018

Accepted: April 15, 2018

Published: April 18, 2018

Copyright $\odot 2018$ by authors and Open Access Library Inc.

This work is licensed under the Creative Commons Attribution International License (CC BY 4.0).

http://creativecommons.org/licenses/by/4.0/

\section{(c) (i) Open Access}

\begin{abstract}
The Recruitment Pattern of Liza falcipinnis from Elechi creek of Upper Bonny, Niger Delta, Nigeria was studied from (March 2009-January 2010). The pattern showed all year round recruitment with two peaks (one major and one minor) during the period of the study. The parameters obtained were $\mathrm{L}_{\infty}=$ 19.96, $\mathrm{K}=0.40 \mathrm{y}^{-1}, \mathrm{C}=0, \mathrm{WP}=0, \mathrm{t}_{\mathrm{o}}=0$. The $\mathrm{C}$ indicates the amplitude of seasonal growth oscillations (that is, the magnitude of the growth patterns) and has values ranging from 0 to 1.0. Winter Point (WP) indicates the times of the year during which growth is minimal. The percentage recruitment for the different months were: March 2009 (15.0\%); April (23.40\%); May (14.0\%); June (11.3\%); July (10.0\%); August (7.30\%); September (1.8\%); October (0.5\%); November (2.2\%); December (8.0\%) and January 2010 (6.0\%). The exploitation rate $\left(\mathrm{E}_{\max }\right)$ that gives maximum relative yield-per-recruit was 0.424 . The exploitation rate at which marginal increase occurred in the relative yield-per-yield was $10 \%$ of its value at $\mathrm{E}=0$, whereas $\left(\mathrm{E}_{0.1}\right)$ was observed to be 0.357 . The exploitation rate $\left(\mathrm{E}_{0.5}\right)$ which corresponds to $50 \%$ of the virgin (that is, the unexploited stock) relative biomass-per-recruit was estimated to be 0.279 . The mean ratio of length-at-first capture $\left(L_{\infty}\right)$ and asymptotic length $\left(\mathrm{L}_{\infty}\right)$ was 0.060 , while that of natural mortality $\left(\mathrm{yr}^{-1}\right)$ and growth rate $\left(\mathrm{yr}^{-1}\right)$ was 1.00 . Yield per increased gradually with increase in exploitation and Biomass per recruit declined with increase in exploitation. An all year round recruitment, with one high pulse arid a low pulse was established for the species. Research should be carried out to ascertain the influence of environmental factors on the growth and recruitment of the species.
\end{abstract}

\section{Subject Areas}

Aquaculture, Fisheries \& Fish Science 


\section{Keywords}

Mullet, Recruitment Pattern, Elechi Creek, Niger Delta

\section{Introduction}

Recruitment is the entrance of young fish into the exploited fishing area and became liable to contact with fishing gear [1]. It also refers to either the addition of new fish to the vulnerable population by growth from among smaller size to bigger individuals [2]. Recruitment is the major source of variability in fish population [3]. The mean age of fish at recruitment generally depends on the type of mesh size of the gear used in fishing. The recruitment pattern or fish entry into the catch is as a result of the combined effect of recruitment and gear selectivity. The general form of recruitment curve may be determined by a proper knowledge of the biology of the species and estimation of the recruitment pattern obtained by comparing the size composition of actual catches with known selectivity of the gear. Knife edge recruitment model identified in Beverton and Holt [4] yield-per-recruit model [5] predicts all fish of a certain age below the age of recruitment which recruit (enter) into fishery but are not exposed to fishing mortality.

Liza falciinnis (Plate 1) belongs to the family Mugilidae. Detailed morphometric and meristic description of Liza falcipinnis are given in the FAO identification sheet, 1974 series [6]. The sickle fin mullet Liza fa1cipinnis has a prominent adipose tissue which surrounds the eye. It has a pectoral fin with auxiliary scale or without an upper lip lacking papilla and ornamentation, maxilla pad is visible below the corner of the mouth when the mouth closes. The anal fin has 3 spines and 11 soft branched rays and lateral line scale of $35-37 \mathrm{~cm} \mathrm{[6].} \mathrm{According} \mathrm{to}$ Idodo-Umeh [6], L. falcipinnis is common in the ocean but occasionally found in the rivers. It is also found in surface water of the ocean and also inhabit coastal marine, estuaries and brackish water.

Factors affecting fish distribution and abundance have already been reported by different workers. Availability of food, spawning rates, breeding grounds

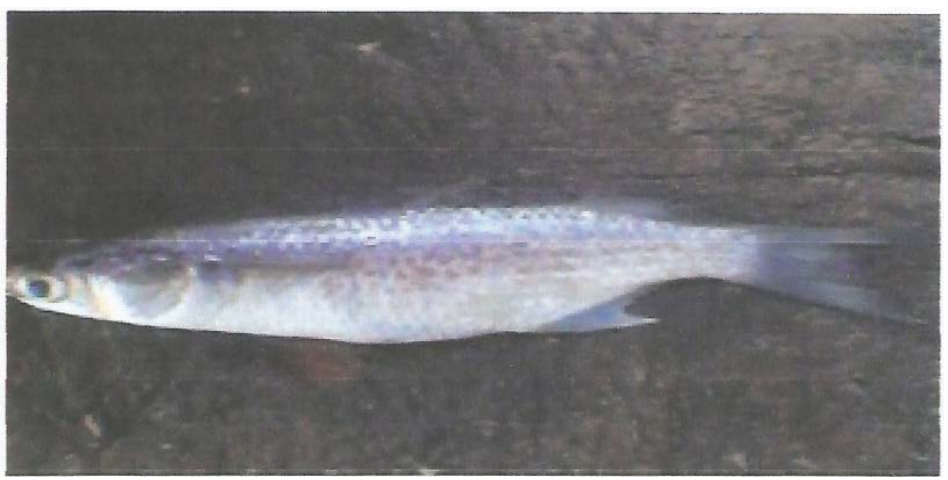

Plate 1. Liza falciinnis (Mullet). 
coupled with shelter, presence of current, vegetation, depth of water, breeding migration and low predation have been suggested as major limiting factors affecting the distribution and abundance of various families by Lelek and El-Zarka, [7]; Kainji Lake; [8] [9] [10] [11] [12]. Allison et al. [13] [14] also reported that fish abundance varied with type of gear used, tidal condition and period of capture, diurnally and seasonally. From the works of Ezenwa et al., [15], Tobor [16] [17] [18], it is clear that most commercially and scientifically important fish species occurring in the Niger Delta waters can be landed all year round by artisanal fishers but there are months when they are more abundant. Tobor [19] reported that it was more abundant in the dry season.

Various studies on its morphometric characteristics have been carried out. These include Houde, [19] on Liza vaigiensis and Liza abu in Caspian Sea, Oren [5] on Liza saliens and L. auratus in Black Sea and Caspian Sea respectively. Morphometric and meristic characteristics have been the most widely used tools in the studies of fishes [20]. Various studies on fish in different water bodies have been carried out. Most of these studies were on fish species composition, abundance and distribution. Among these are [9]; River Niger, [21]; Odo-ona stream in Ibadan, [22], Otamri River, [23]; Oguta Lake [24]; Bonny River, [25]; Kolo Creek and [26]; Lower Nun River. Others include [27]; Brass River, [28]; Lower Nun River and [29], Elechi Creek.

Most of the literatures of Mugilidae are on places other than the Elechi Creek. Green, [30]; Migdalski and Frichter [31], Thomson [32], King [33] and Ita and Balogun [34] reported on Mugil cephalus from subtropical seas, Coast of North America and West Africa, Qua Ibo River and Oguta Lake respectively. Others who also reported on different species of Mugilidae are; Mahmoud [35]; Mugil saheli (Suez, Egypt), Fernandez-Delgado and Rossomanno [36]; Sharp nose mullet, Caspian Sea. Magdy [37] and Rahmah [38]; Liza saliens (South east Caspian sea). The mugilids are essentially pelagic and scarcely present below a depth of $25 \mathrm{~m}$ [39]. Juvenile mugilids prefer dark places in shallow coastal water, thus their distribution is the estuaries [33]. The fish is very popular, well relished and forms a large proportion of the diets of riparian communities. This is probably because of the high quality and highly flavoured flesh of the fish [32].

The Elechi Creek is one of the most important river systems in the Niger Delta providing nursery and breeding grounds for a large variety of fish species. However, owing to industrialization and recreational activities, this creek is fast becoming degraded. In the Elechi Creek, Liza falcipinnis occurs throughout the year. However, this occurrence is predominant in the dry season [33]. They are mostly seen along the banks of creek during high tide and on sandy and muddy substrates [33]. Mugilidae have a world-wide distribution and inhabit mainly tropical and temperate seas [33]. According to Nelson [40], the family Mugilidae includes 17 genera and 80 species in the world. Three mugilid species including golden mullet (Liza auratus), sharpnose mullet (Liza saliens), and striped mullet, Mugil cephalus were first transplanted from the Black sea to the Caspian Sea 
between 1930 and 1934 by the Soviet authorities [41]. The first two species are now common in the Iranian coast of the Caspian Sea and mature earlier than those inhabiting the Black Sea [42].

Among the family of Mugilidae the species well studied is the Mugil cephalus or grey mullet, hence more information about Mugil cephalus is available. Mugil cephalus is abundant and distributed in the coastal waters of West Africa [32]. In Nigeria, it is widely distributed along the brackish estuaries and coastal waters. It is very popular, well relished and forms a large proportion of the diets of riparian communities. This is probably because of the high quality and highly flavoured flesh of the fish. Eisawy et al., [43], carried out rearing of mullets in Egyptian fish farms. Hamza and Zaki [44] also carried out rearing experiment of some marine fishes in brackish water system including grey mullet (Mugil sahe1i) which also belong to family Mugilidae and their fry are present in big amounts in Gulf of Suez, especially Suez Bay Magdy [38]. Biological studies are particularly important for describing the status of a fish population and for predicting the potential yield of the fishery. It is essential to study the recruitment pattern of Liza Falcipinnis to provide information for studying its growth rate, age at maturity, longevity, spawning, production, stock size, recruitment to adult stock and mortalities [45] [46] for management decisions.

\section{Materials and Methods}

\subsection{Study Area}

The study was carried out at Elechi Creek, a tributary of Upper Bonny River Estuary, Niger Delta and its adjoining mangrove creeks situated near Eagle Island. It is a stream in Nigeria, West Africa, Africa. It is located in Latitude: $4^{\circ} 46^{\prime} 3.4^{\prime \prime}\left(4.7676^{\circ}\right)$ north; Longitude: $6^{\circ} 59^{\prime} 12.6^{\prime \prime}\left(6.9868^{\circ}\right)$ east. Its Elevation is 425 meters (1394 feet). The Bonny River Estuary is between latitude $4^{\circ} 45^{\prime} \mathrm{N}$ and $7^{\circ} 15^{\prime} \mathrm{N}$ and longitude $4^{\circ} 30^{\prime} \mathrm{E}$ and $4^{\circ} 37^{\prime} \mathrm{E}$. The Niger Delta basin covers all land between latitude $4^{\circ} 15^{\prime} \mathrm{N}$ and $500^{\circ} 36^{\prime} \mathrm{N}$ and longitude $5^{\circ} 25^{\prime} \mathrm{E}$ and $7^{\circ} 37^{\prime} \mathrm{E}$ with total area of $200,000 \mathrm{~km}^{2}$ [45]. It extends along the coast from the river basin in the West of the Bonny River and in the East, it encompasses the pro-Niger Delta Basin and, most part of the Delta Basin province of Delta State. It is characterized by extensive interconnection of creeks. It covers about $20 \%$ of the surface area of Nigeria [47]. The annual rainfall of the Niger Delta is between $300-3000 \mathrm{~mm}$ per year [45]. The tidal influence is very pronounced as we experienced two tidal levels daily, high and low tides. The Elechi Creek, a tributary of Upper Bonny River Estuary is situated between longitude $6^{\circ} 51^{\prime} \mathrm{E}$ and $7^{\circ} 10^{\prime} \mathrm{E}$ and latitude $4040 \mathrm{k}$. The stretch of the river is long and wide with meanders. The vegetation is predominantly mangrove. The low intertidal is dominated mostly by Rhizophora racemosa, Rhizophora mangle while the high intertidal is dominated by Avicennia africana, Laguncularia racemosa, Nypa fruiticans and Aerosticuchum auecum [48]. 


\subsection{Sample Collection}

Sampling was carried out from March, 2009-January, 2010. Specimens were randomly collected from landings from fishers from the Elechi creek. Specimens collected were conveyed in cooler boxes containing ice chips to the laboratory, on each sampling thy. Sampling was carried out twice a month. Fish specimen was properly identified using monographs, descriptions, checklist and keys of Needham and Needham [48]; Reed et a1., [49]; Holden and Reed, [50], FAO [51], Leveque et al, [52] and Olaosebikan and Raji [53]. In the laboratory, total lengths; were measured with fish measuring board to the nearest centimeter. Girth was measured with tailor tape to nearest centimeter $(\mathrm{cm})$. The weight of each fish was obtained by weighing fish specimen on a sensitive weighing balance (Sartorius model RS, Germany) to nearest gram (g), The female and the male Liza falcipinnis were identified through dissection. The female has two ovaries while the male has the testes [54]. The relative yield-per-recruitment $(\mathrm{Y} / \mathrm{R})$ and relative biomass-per-recruitment were determined by the knife-edge recruitment approach which is identified by Beverton and HoIt [4] as yield-per-recruit model and incorporated into the recruitment routine in FISAT [5] [55]. In FISAT, the recruitment patterns were analyzed using the maximum likelihood approach of NORMSEP (Separation of the normally distributed components of length-frequency samples) to fit the Gaussian distribution on length-frequency data for the year pooled together [4] [55] [56].

\section{Results}

The recruitment pattern of $L$ falcipinnis from Elechi Creek Bonny River Estuary, Niger Delta is shown in Figure 1. The pattern showed all year round recruitment with two peaks (one major and one minor) during the period of the study. the parameters obtained were $\mathrm{L}_{\infty}=19.96, \mathrm{~K}=0.40 \mathrm{y}^{-1}, \mathrm{C}=0, \mathrm{WP}=0, \mathrm{t}_{\mathrm{o}}=0$. The $\mathrm{C}$ indicates the amplitude of seasonal growth oscillations (that is, the magnitude of the growth patterns) and has values ranging from 0 to 1.0. Winter Point (WP) indicates the times of the year during which growth is minimal. The percentage recruitment for the different months were: March 2009 (15.0\%); April (23.40\%); May (14.0\%); June (11.3\%); July (10.0\%); August (7.30\%); September $(1.8 \%)$; October (0.5\%); November (2.2\%); December (8.0\%) and January $2010(6.0 \%)$.

Figure 2 shows the relative yield-per-recruit (Y/R) and relative biomass-per-recruit $(\mathrm{B} / \mathrm{R})$ analysis by the knife-edge selection method. The exploitation rate $\left(\mathrm{E}_{\max }\right)$ that gives maximum relative yield-per-recruit was 0.424 . The exploitation rate at which marginal increase occurred in the relative yield-per-yield was $10 \%$ of its value at $\mathrm{E}=0$, whereas $\left(\mathrm{E}_{0.1}\right)$ was observed to be 0.357 . The exploitation rate $\left(\mathrm{E}_{0.5}\right)$ which corresponds to $50 \%$ of the virgin (that is., the unexploited stock) relative biomass-per-recruit was estimated to be 0.279 . The mean ratio of length-at-first capture $\left(\mathrm{L}_{\infty}\right)$ and asymptotic length $\left(\mathrm{L}_{\infty}\right)$ was 0.060 , while that of natural mortality $\left(\mathrm{yr}^{-1}\right)$ and growth rate $\left(\mathrm{yr}^{-1}\right)$ was 1.00 . 


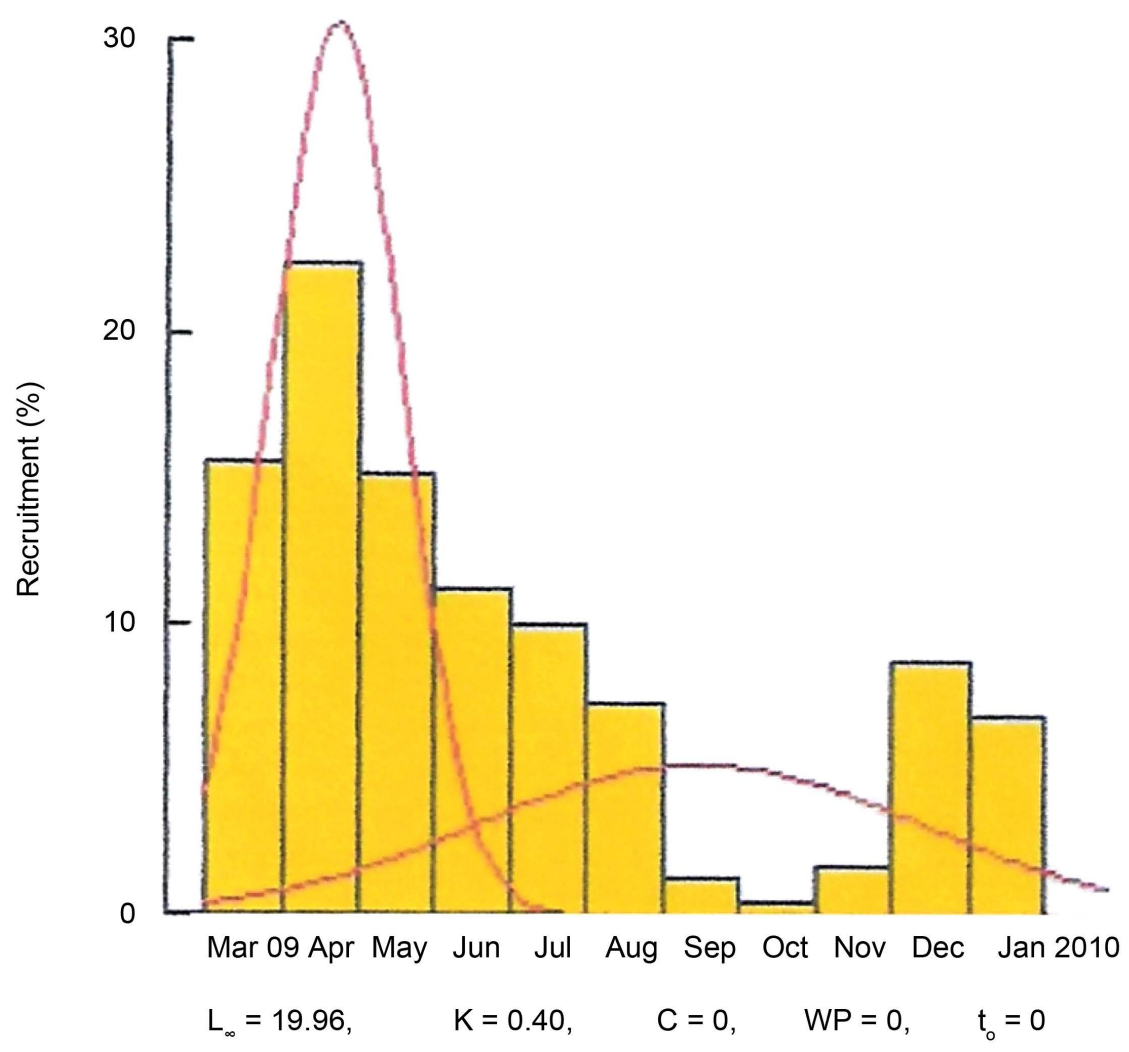

Figure 1. Recruitment pattern of $L$. falcipinnis from Elechi Creek.

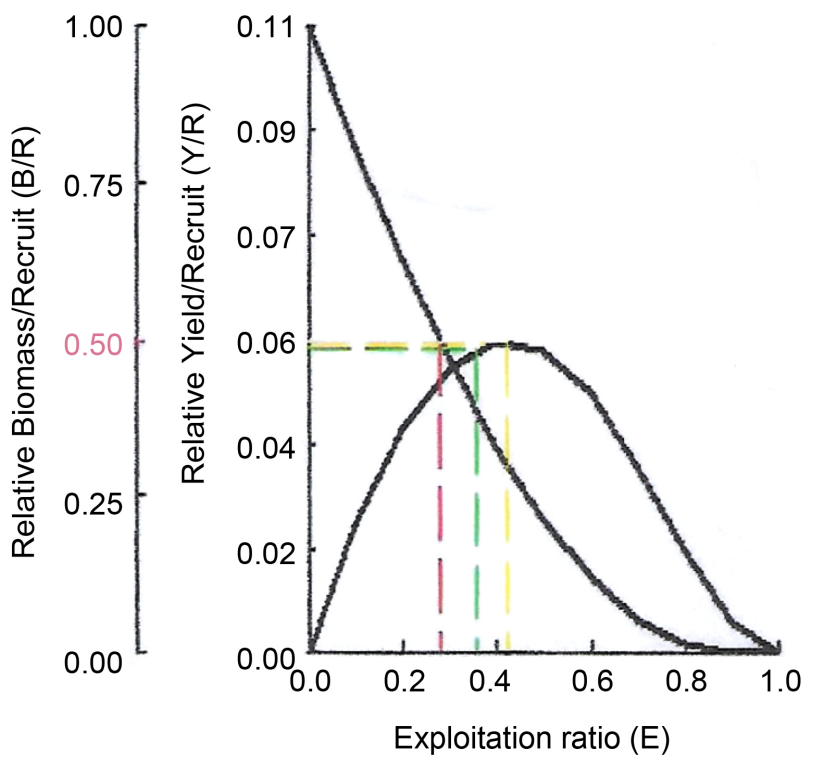

Figure 2. Relative yield-per recruit and relative biomass-per recruit of $L$. falsipinnis using the knife-edge recruitment method.

(Table 1). Table 2 shows the relative biomass/recruit and relative yield/recruit per exploitation of $L$. falcipinnis. Yield per increased gradually with increase in exploitation and Biomass per recruit declined with increase in exploitation. 
Table 1. Estimated mortality parameters, Optimum exploitation rate and relative coefficient rate of $L$. falsipinnis from Elechi creek.

\begin{tabular}{cccccccccc}
\hline Parameters & $\mathrm{Z}$ & $\mathrm{M}$ & $\mathrm{F}$ & $\mathrm{E}$ & $\mathrm{E}_{\mathrm{MAX}}$ & $\mathrm{E}_{0.1}$ & $\mathrm{E}_{0.5}$ & $\mathrm{LC} / \mathrm{L}_{\infty}$ & $\mathrm{M} / \mathrm{K}$ \\
\hline & 1.28 & 1.00 & 0.28 & 0.22 & 0.424 & 0.357 & 0.279 & 0.060 & 1.00 \\
\hline
\end{tabular}

Key: $\mathrm{Z}=$ Total Mortality, $\mathrm{M}=$ Natural Mortality, $\mathrm{F}=$ Fishing Mortality, $\mathrm{E}=$ Exploitation, $\mathrm{E}_{\mathrm{MAX}}=$ Maximum exploitation, $\mathrm{E}_{0.1}=10 \%$ exploitation, $\mathrm{E}_{0.5}=5 \%$ exploitation, $\mathrm{LC} / \mathrm{L}_{\infty}=$ the ratio of length at-capture to the asymptotic length, $\mathrm{M} / \mathrm{K}$.

Table 2. The relative biomass/recruit and relative yield/recruit per exploitation of $L$. falcipinnis from Elechi creek.

\begin{tabular}{ccc}
\hline Exploitation & Yield/Recruit & Biomass/recruit \\
\hline 0.10 & 0.022 & 0.805 \\
0.20 & 0.039 & 0.627 \\
0.30 & 0.050 & 0.468 \\
0.40 & 0.055 & 0.329 \\
0.50 & 0.053 & 0.213 \\
0.60 & 0.046 & 0.122 \\
0.70 & 0.033 & 0.057 \\
0.80 & 0.018 & 0.018 \\
0.90 & 0.005 & 0.002 \\
1.00 & 0.000 & 0.000 \\
\hline
\end{tabular}

\section{Discussion}

The all year round and double recruitment pattern per year obtained for $L$. falcipinnis of the Elechi Creek conforms to the assertion of Rufli and Van Lissa [57] and Paul [58] respectively that they are characteristics of most tropical fish stocks with seasonal association. The recruitment pattern of this fish showed peak recruitment in April 2009 and another December 2009. Rabuor et al. [59] observed a main recruitment pulse from September 2002 to January of the following year and minor pulse in June and suggested that the Nile perch in Lake Victoria probably spawns twice a year. However, for Oreochromis leucosticus in Lake Naivasha, Kenya recruitment occurred throughout the year with peaks in February and at the end of July [60]. Aripin and Showers [61] reported an all year round recruitment pattern in seven small pelagic fishes with two peak periods. Francis [62] observed lowest recruitment during periods of least abundance in artisanal catches of the Andoni River and reported recruitment as good guide to knowing periods of fish abundance; that young fishes usually predominate in catches during the recruitment periods which is usually evident from the length-frequency distribution plot. Ikomi and Sikoki, [63] reported a onetime recruitment pattern a year between November and December when there was a dominance of young adults in the population. This conforms to this study which recorded recruitment in April and May 2009. The amplitude of seasonal growth oscillation (C) observed at (0.00) indicated that L. falcipinnis from this study 
area experienced no seasonality in growth. According to Pauly [64] growth oscillation is due mainly to temperature changes.

\section{Conclusion and Recommendation}

- An all year round recruitment, with one high pulse arid a low pulse was established for the species.

- Research should be carried out to ascertain the influence of environmental factors on the growth and recruitment of the species.

\section{References}

[1] Gayamlo Jr., F.C., Sparre, P. and Pauly, D. (1995) FAO-ICLARM Stock Assessment Tools (FISAT). Users Manual FAO Compi. Info. Ser. (Fisheries) No. 8, 125 p.

[2] Ricker, W.E. (1977) The Historical Development. In: Gulland, J.A., Ed., Fish Population Dynamics, John Wiley \& Sons. Ltd., 1-26.

[3] Bankole, N.O. (1990) Gilinet Monitoring at Tiga and Jakaran Reservoir in Kano State. National Institute of Fresh Water Fisheries Research (NIFFR) Annual Report, $39-42$.

[4] Beverton, R.J. and Holt, S.J. (1957) On the Dynamics of Exploited Fish Populations. Ministry of Agriculture, Fisheries and Food Investigations, UK, Series 2, 19.

[5] Oren, O.H. (1981) Aquaculture of Grey Mullet. In: Oren, O.H., Ed., Biol. Prog, Cambridge Univ. Press, 411-493.

[6] Idodo-Umeh, G. (2003) Freshwater Fishes of Nigeria. Taxonomy, Ecological Notes, Diet and Utilization, Iclodo Umeh Publishers Ltd., 19-20.

[7] Lelek, A. and El-Zarka, S. (1993) Ecological Comparison of the Preimpounded Fish Faunas of the Niger and Kainji Lake, Nigeria, Geophys. Monogaph, 17, 655-660.

[8] Imevbore, A.M.A. and Okpo, W.S. (1975) Aspect of the Biology of Kainji Lake Fisheries and Ecology of Lake Kainji. The Transition from River to Lake, Kainji, 116-179.

[9] Willoughby, N.G. (1994) The Ecology of the Genus Synodontis (Pisces: Siluroidei in Lake Kainji Nigeria. PhD. Thesis University of Southampton, 288 p.

[10] Akintunde, E.A. (1976) The Biology of Tilapia and Sarotherodon Species of Lake Kainji Nigeria with Special Reference to Sarotherodon galilaeus. M.Sc. Thesis University of Nigeria, $200 \mathrm{p}$.

[11] Olatunde, A.A. (1977) The Distribution, Abundance and Trends in the Establishment of the Family Schilbeidae (Osteicthyes: Siluriformes) in Lake Kainji, Nigeria. Hydrobiologia, 56, 69-80. https://doi.org/10.1007/BF00023287

[12] Ita, E.O. (1978) Analysis of Fish Distribution in Kainji Lake, Nigeria. Hydrobiologia, 58, 233-244. https://doi.org/10.1007/BF02346958

[13] Allison, M.E., Gabriel, U.U., Inko-Tariah, M.B., Davies, O.A and Udeme Naa, B. (1997) The Fish Assemblage of Elechi Creek, Rivers State, Nigeria. Niger Delta Biologia, 2, 59-73.

[14] Ezenwa, B., Alegbeyele, O., Njwumba, A. and Anyanwu, P. (1987) Cultivable Fish Seeds in Nigeria. Waters-A Research Survey (1978-85). Proceeding of the Annual Conference of the Fisheries Society of Nigeria (FISON), Port Harcourt, 99-112.

[15] Tobor, J.G. (1991) Marine Fish Resources of West Africa: Potentials, Management, Development and Constraints to Their Utilization to Satisfy Increasing Demand. 
Technical Paper 70, NIOMR, Lagos, 1-25.

[16] King, R.P. (1991) The Biology of Tilapia Mariae. (Boulenge, 1899) (Pereiformes: Cichlidae). A Nigerian Rainforest Stream. Ph.D. Thesis, University of Port Harcourt, Nigeria.

[17] Hart, A. (1997) The Biology of Mugil cephalus in Bonny River Estuary. M.Sc. Thesis, University of Port Harcourt, Port Harcourt, 10-42.

[18] Houde, E.D. (1987) Fish Early Life Dynamics Recruitment Variability. America Fisheries Society Symposium, 2, 17-29.

[19] Trewaves, E. (1983) Tilapia Fishers of the Genera, Sarotherodon, Oreochromis, and Danakila. The Doret Press, Dorchester, 583 p. https://doi.org/10.5962/bhl.title.123198

[20] Sydenham, D.H. (1975) Observation on the Fish Population of Nigeria Forest Streams. Zoology Review, 80, 257-272.

[21] Ogbo, E.A. (1982) Identification of Commonly Found Fresh Water Fishes of the Otamiri River, Imo State. HND Project, Rivers State University of Science and Technology, Port Harcourt, 64 p.

[22] Nwadiaro, C.S. (1989) Ichthyofauna of Lake Oguta, a Shallow Lake in South-Eastern Nigeria. Archiv für Hydrobiologie, 115, 463-475.

[23] Chindah, A.C. and Osuamkpe, A. (1994) The Fish Assemblage of the Lower Bonny River, Niger Delta, Nigeria. African Journal of Ecology, 32, 58-65. https://doi.org/10.1111/j.1365-2028.1994.tb00555.x

[24] Alfred-Ockiya, J.F. (1996) Studies on the Ichthyofkuna of Kolo Creek, Rivers State. Niger Delta Biologia, 1, 24-28.

[25] Sikoki, F.D. and Hart, S.A. (1999) Studies on the Fish and Fisheries of Brass River System and Adjoining Coastal Waters in Bayelsa State, Nigeria. Journal of Applied Science and Environmental Management, 2, 63-67.

[26] Abowei, J.F.N. (2000) Aspects of Fisheries of the Lower Nun River Nigeria. Ph.D. Thesis, University of Port Harcourt, Port Harcourt, 248 p.

[27] Din, M.S. (2003) Length-Weight Relationship of Sarotheredon melanotheron and Tilapia guneensis in Elechi Creek, Niger Delta, Nigeria. B.Sc. Project, Rivers State University of Science and Technology, Port Harcourt, 13 p.

[28] Green, J. (1968) The Biology of Estuarine Animals. Sidgwick and Jackson, London, England, 284-286.

[29] Migdalski, E.C. and Frichter, G.S. (1976) Fresh and Salt Water Fishes of the World. Knopf, New York.

[30] Thomson, J.M. (1981) Species Identifications Sheet for Fisheries Purposes. Eastern Central Atlantic Fishing Area 34 and Part of 47. Food and Agriculture Organization of the United Nations, Rome.

[31] King, R.P. (1984) On the Biology of the Mugilidae in Bonny River (Niger Delta, Nigeria) with Particular Reference of Feeding Ecology. M.Sc. Thesis, Department of Zoology, University of Port Harcourt, Port Harcourt.

[32] Ita, E.O. and Balogun, J.K. (1983) A Feasibility Report of the Fisheries Development Potentials of Oguta Lake (Owerri Nigeria) and a Discussion on the Fisheries Development Potyentials of the Anambrallino River Basin Area. A Report Prepared Bu Kanyi Lake Ressearch Inst. (Fisheries-Dev) for Anambra/Imo River Basin Devt. Autho. KLRI, New Bussa, Nigeria.

[33] Mahmoud, W.F. (1997) Reproduction and Physiological Characters of Mugil Saheli in Fish Farms. M.Sc. Thesis, Faculty of Science, Suez Canal University, Ismailia. 
[34] Fernander-Delgado, C. and Rossomanno, S. (1997) Reproductive Biology of the Mosquito Fish in a Permanent Natural Lagoon in South-West Spain: Two Tactics for One Species. Journal of Fish Biology, 51, 80-92. https://doi.org/10.1111/j.1095-8649.1997.tb02515.x

[35] Magdy, M.E. (2004) Reproductive Biology of Mugil Saheli (Family Mugilidae) Reared in Fish Farm. Egyptian Journal of Aquatic Research, 30, 234-240.

[36] Rahman, P. (2008) Some Biological Aspects of the Sharpnose Mullet Liza saliens (Risso, 1810) in Gorgan Bay-Miankaleh Wildlife Refuge (the Southeast Caspian Sea). Turkish Journal of Fisheries and Aquatic Sciences, 8, 225-232.

[37] Poll, M. (1959) Expedition occenographique belge dans les eaux cotieres Africaines do l'Alanlique sud (1948-1949): Resultats scientifiques. Vol. W, Fasacule 3B. Poisons: Teleosteens. Alanthopteygiens (Deuxieme partie) Du Mmistere dii congo Beige et. Du Rvarda Ururdi et de l'Association “MB 121", par de soins del l'Institut, Royale des sciences Naturalles de Belgique.

[38] Nelson, I.S. (1994) Fishes of the World. 4th Edition, John Wiley and Sons, New York, $600 \mathrm{p}$.

[39] Berg, L.S. (1965) Freshwater Fishes of the U.S.S.R and Adjacent Countries. 4th Edition, Israel Program for scientific Translations Ltd., Jerusalem, 510 p.

[40] Baliaeva, V.N., Viaseriko, A.D. and Ivanov, V.P. (1989) Caspian Sea: Ichthyotauna and Fisheries Resources. Nauk Press, Russian Academy of Science, Moscow, 255 p.

[41] Eisanwy, A.M., Ishak, A.M. and Hamza, A. (1974) Experimental Rearing of two Species Mugil cephalus and Mugil capito in Egyptian Fish Farms. Bulletin of the Institute of Oceanography and Fisheries, 4, 57-96.

[42] Hamza, A.K. and Zaki, M.I. (1987) Experimental Rearing of Some Marine Fishes in Brackish Water in Egypt. ISR Journal of Aquaculture-Bamdgeh, 2, 39-48.

[43] FAO (1998) Year Book of Fishery Statistics 1996. Food and Agricultural Organization of the United Nations, Rome, 678 p.

[44] Low-McConnel, R.H. (1987) Fish Communities in Tropical Freshwaters. Longman Limited, London, $340 \mathrm{p}$.

[45] Powell, C.B., White, S.A., Ibiebele, D.O., Bara, M., Dutkiewicz, B., Isoun, M. and Otoegbu, E.U. (1985) Oshika Oil Siliage Environmental Impact: Effect on Aquatic Biology. NNPC/ FMHE International Seminar on Petroleum Industry and the Nigerian, Kaduna, Nigeria, November 1985, 168-178.

[46] Powell, C.B. (1987) Three Aipheid Shrimps of a New Genus from West African Fresh and Brackish Waters: Taxonomy and Ecological Zonation (Crstacea Decapoda Natantia). Revue de Zoologie Africaine, 93, 116-150.

[47] Wilcox, H.R.B. and Powell, C.B. (1985) The Mangrove Ecosystem of the Niger Delta: In the Mangrove Ecosystem of the Niger Delta. University of Port Harcourt, Port Harcourt, $55 \mathrm{p}$.

[48] Needham, J.J.G. and Needham, P.R. (1962) A Guide to Study of Fresh Water Biology. 5th Edition, Holden-Day, Inc., Oakland, 108 p.

[49] Reed, W., Buchard, J., Hopson, A.J. and Yaro, I. (1967) Fish and Fisheries of Northern Nigeria. Ministry of Agriculture, Kaduna, Northern Nigeria, 226 p.

[50] Holden, M. and Reed, W. (1972) West African Freshwater Fishers. Longman Limited, London, $36 \mathrm{p}$.

[51] FAO (1981) Methods of Collecting and Analyzing Size and Age Data for Fish Stock Assessment. Food and Agricultural Organisation, Rome, 100 p.

[52] Leveque, C., Pangy, D. and Teugel, G.G. (1991) Annotated Checklist of the Fresh 
Water Fishes of the Nib-Sudan River Basins in Africa. Reverend Hydrobiology, 24, 131-154.

[53] Olaosebikan, B.D. and Raji, A. (1998) Field Guide to Nigerian Freshwater Fishes. Federal College of Freshwater Fisheries Technology, New Bussa, Nigeria, 47 p.

[54] Ntiba, M.J. and Jaccarini, V. (1990) Gonad Spawning Maturation and Times of Sinanus sutor off the Kenya Coast: Evidence for Definite Spawning Season in a Tropical Fish. Journal of Fish Biology, 37, 315-325. https://doi.org/10.1111/j.1095-8649.1990.tb05862.x

[55] Pauly, D. (1983) Length-Converted Catch Curves: A Powerful Tool for Fisheries Research in the Tropics (Part 1). Fishbyte, 1, 9-13.

[56] Moreau, J. and Cuende, F. (1991) On Improving the Resolution of the Recruitment Patterns of Fishes. Fishbyte, 9, 45-46.

[57] Rufli, H. and Van Lissa, J. (1982) Age and Growth of Engraulicypris sardella in Lake Malawi. Biological Studies on the Ecosystem of Lake Malawi, Technicxal Report, FAO, Rome, 85-97.

[58] Pauly, D. (1982) Studying Single-Species Dynamics in a Tropical Multispecies Context. In: Pauly, D. and Murphy, G.L., Eds., Theory and Management of Tropical Fisheries: ICLARM Conference Proceedings, ICLARM, Manila, 33-70.

[59] Rabour, C.O., Moreau, J. and Manyala, J.O. (2003) Growth, Mortality and Recruitment of Nile Tilapia (Oreochromis niloticus) (Cichlidae) in Lake Turkana (Kenya): Possible Variations as Assessed by Length Frequency Analysis. African Journal of Tropical Hydrobiology and Fisheries, 8, 26-34.

[60] Njiru, M. and Ojuok, J.E. (1996) Picopulation Parameters of Oreochromis levcostictus from Lake Naivasha, Kenya. African Journal of Tropical Hydrobiology and Fisheries, 7, 17-21.

[61] Aripin, I.E. and Showers, P.A.T. (2000) Population Parameters of Small Pelagic Fishes Caught off Tawi-Tawi, Philippines. Naga, 23, 21-26.

[62] Francis, A. (2003) Studies on the Icthyofauna of the Andoni River System in the Niger Delta of Nigeria. Ph.D. Dissertation, University of Port Harcourt, Port Harcourt, $273 \mathrm{p}$.

[63] Ikomi, R.B. and Sikoki, F.D. (2001) Studies on the Distribution, Abundance Growth Pattern Dietary Habits of Brycinus nures Ruppel, 1832 (Osteichthyes: Characidae) in the River Jamieson, Nigeria. Acta Ichthyologica et Piscatoria, 31, 27-43. https://doi.org/10.3750/AIP2001.31.1.02

[64] Pauly, D. (1987) A Review of the ELEFAN System for Analysis of Length-Frequency Data in Fish and Aquatic Invertebrates. In: Pauly, D. and Morgan, G.R., Eds., Length-Based Methods in Fisheries Research: ICLARM Conference Proceedings, ICLARM, Manila, 6-34 p. 